\title{
Resort-oriented tourism development and local tourism networks - a case study from Northern Finland
}

\author{
OUTI KULUSJÄRVI
}

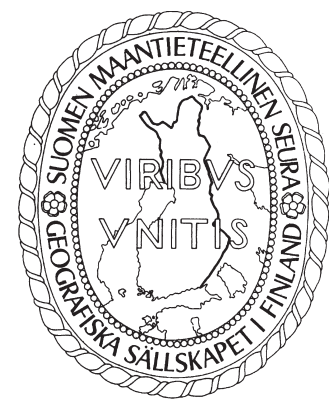

Kulusjärvi, Outi (2016). Resort-oriented tourism development and local tourism networks - a case study from Northern Finland. Fennia 194: 1, 3-17. ISSN 17985617.

In tourism studies, it has been widely recognized that resort-oriented tourism development creates challenges for regional development, mainly due to its enclave nature and lack of regional economic linkages. However, there have been relatively few studies on the destination-scale cooperative networks, although, they are vital in increasing the positive regional economic impacts of tourism development. This paper is an empirical qualitative study exploring the connections between resort-oriented tourism development and tourism business cooperation in the case study area of the Ruka-Kuusamo tourism destination in Northeast Finland. The interest is on how the local cooperative networks of the Ruka tourist resort are spatially constructed within the Ruka-Kuusamo tourism destination. The research data consists of semi-structured interviews conducted for ten tourism actors located in the Ruka resort. The results show that the businesses located in the Ruka resort cooperate at the regional scale mainly in marketing, while their partners in production cooperation are located mostly within the resort, particularly in its very core area. The resort appears to function as a basis for spatial identification for tourism actors, which, in turn, affects entrepreneurs' motivation to cooperate at the local and regional scale. Tourism entrepreneurs operating in the very core of the resort perceive the area as the principal area for their operations, and therefore, they do not particularly engage with the surrounding areas and businesses or with other actors located there. Thus, for smaller enterprises outside the core, it can be difficult to benefit from the resort's core's growth via network relations. This contributes mainly to the development of the core areas alone, creates challenges for sustainable regional economic development in the destination region, and hinders the resort's tourism growth in the long run.

Keywords: tourism destination development, cooperation, enclave resorts, sustainable regional development, qualitative study, Finland

Outi Kulusjärvi, Department of Geography, University of Oulu, PO Box 3000, Fl-90014 Oulu, Finland. E-mail outi.kulusjarvi@oulu.fi

\section{Introduction}

Experiencing the tranquility of the natural environment is a frequent need for many individuals. The characteristics of the periphery offer counterpoint to the everyday environment of the citizens of urban core areas, as a result of which rural areas are often regarded as attractive tourism destinations (Montanari \& Williams 1995: 6). For instance, in the peripheries of Scandinavia, the attractiveness of the natural environment has been used as a basis for developing tourism into a significant new branch of industry. Nevertheless, typically tourist flows largely concentrate there in core areas. For example, in Northern Finland, the tourism industry has been developed around winter sport activities, and hence, tourist flows largely concentrate on tourist resorts located near fells. In other words, tourism development is resort-oriented. 
In Finland, at all spatial scales, from local to national, tourism is developed by supporting resorts and their enterprises. Tourism growth is sought by increasing particularly international tourism demand (Työ- ja elinkeinoministeriö 2010: 15, 19). As mentioned by Müller and Brouder (2014), tourism businesses in the peripheries of Scandinavia have had to pool their resources due to the demands of globalization, i.e. in order to gain international visibility. As tourism grows and becomes more international, tourism enterprises in the resorts are typically also increasingly national or international operators. In consequence, destinations tend to become spaces homogenous with each other. For instance, skiing destinations in Northern Finland are transforming towards the resort structures similar to Central European alpine destinations. At the same time, they weaken their linkages with the local communities in their surroundings (Saarinen 2004: 161, 169-171). In these circumstances, the positive economic impacts of tourism typically remain mainly within the areas occupied by tourists and do not spread beyond the resort into the surrounding peripheral areas (Britton 1982; Walpole \& Goodwin 2000: 572). The described development in Northern Finland is similar to the more extreme enclave development of tourist resorts in the developing world.

Even though tourism is commonly considered as one of the only industries with positive future prospects and potential to revitalize declining rural regional economies, tourism growth does not automatically lead to rural development (Saarinen 2008: 101). As Ribeiro and Marques (2002: 212) have noted, there is often a gap between the expected and realized socio-economic benefits of tourism development for a regional economy. For this reason, it is also necessary to look at the development of tourist resorts from the perspective of sustainability in a wider tourism region and in local communities. Resort-oriented tourism development can be appropriate and successful in terms of business growth, at least in the short-term. Also, a resort's growth can create tax income for the municipality and, at least to some extent, business opportunities and employment for local people. In the regions of resort-oriented tourism development, there are challenges related to the socioeconomic impacts of tourism. This paper argues that the positive employment and economic benefits of tourism should impact to the greatest possible extent the residents of the destination region. Where this holds true, these matters can be ex- pected to contribute to the well-being of the local community.

In order to distribute the benefits of resort-oriented tourism development equitably within a wider region than the resort alone, cooperation between the core and the surrounding periphery is vital. In Finnish tourism planning (Työ- ja elinkeinoministeriö 2010; Lapin liitto 2011; Pohjois-Pohjanmaan liitto 2011), it is expected that resorts and other functional cores (such as municipality centers) work as engines within which enterprises located in the surrounding peripheral areas can network and thereby benefit from the resorts' tourism growth. It is presumed that core-periphery cooperation can effectively distribute the positive impacts from the resorts to a wider region. However, the ways in which the cooperation ought to happen have not been specified in the strategies. Furthermore, there have been relatively few studies on destination-scale cooperation networks in tourism research.

In the current study, new insights on the role of local-scale tourism cooperation in rural tourism areas of resort-oriented development will be searched for. The case study area is the municipality of Kuusamo in Northeast Finland (Fig. 1). In the study, the focus is on the Ruka tourist resort, which draws most of the tourists travelling to Kuusamo. Ruka is best known as a winter tourism destination and, measured by its ski ticket revenue, it is the second largest ski resort in Finland. Still, as Kauppila (2011: 28) has pointed out, the development of tourism in Ruka has not been able to save the municipality of Kuusamo from high unemployment and population loss.

The aim of the present paper is to critically engage with the interrelations between the resortoriented tourism development and attendant construction of the local cooperation networks of tourism enterprises. The state of networking of tourism businesses located in tourist resorts in rural areas will be examined. The paper asks: How are the local tourism business cooperative networks of a tourist resort spatially constructed within the regional tourism destination? In the current preliminary study, the topic is studied from the viewpoint of the enterprises located in the Ruka tourist resort. That is, the focus is on the linkages that enterprises located in Ruka have within and beyond the resort. Hence, all the interviewed tourism actors are located in the resort. The interest here is not necessarily in the cooperation between the resort and the surrounding pe- 
Fig. 1. Case study area Kuusamo municipality and tourist resort Ruka in north-eastern Finland.

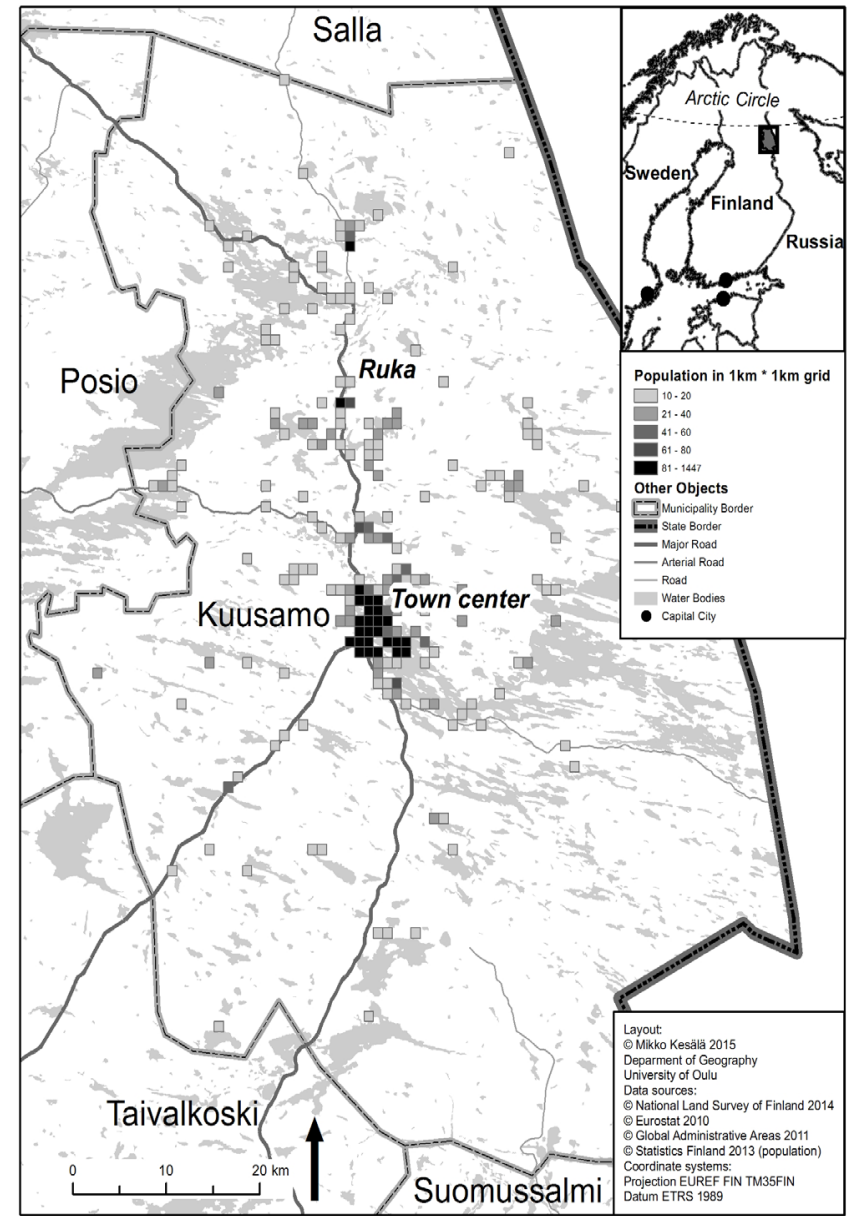

riphery, but in examining what the core area of tourism is and how it is (re)produced by way of tourism business networking.

The theoretical background of this study is based on the research literature of regional development studies in tourism geography and on the research of relational economic geography, which will be introduced in the following section. After this, the case study area of Ruka-Kuusamo and its recent tourism developments will be briefly introduced. Afterwards, there will be an overview of the research materials and analysis. The results chapter will be divided into two subsections, the first covering cooperation taking place at the regional scale, and the second concerning coopera- tion concentrating to the resort. In the discussion and conclusions, the paper will consider the current state of networking as regards to sustainable tourism and regional development. Also, needs for future research will be presented.

\section{Tourism and peripheral development}

\section{Tourism for regional development}

The positive economic impacts of tourism on regional development are often the major motivator for developing tourism, which is viewed as a way 
to generate income and employment for local people residing in declining rural areas (Williams \& Shaw 1998: 11). However, as has been recognized, tourism is not a self-evident tool for regional development (e.g. Oppermann 1996; Ribeiro \& Marques 2002). Thus, the goals of tourism development should not be set before the needs of other local livelihoods and tourism should be developed as one industry alongside others. Burns (1999) has underlined that the main target in tourism planning should not be tourism growth but improvement of social well-being. In his view, instead of a tourism-first approach, tourism planning should be carried out from a developmentfirst approach. That is, tourism should be used only as one of many possible development tools. Saarinen (2006: 47) has similarly emphasized that traditional local industries should be valued equally alongside tourism.

Burns (2004) has later paid close attention to the challenges of carrying out tourism planning and policies from the perspective of sustainable regional development. Commonly, tourism planning is conducted from the perspective of tourism industry only, which can lead to neglecting the needs of other livelihoods. In addition, planning is limited to the scale of administrative units and connections across those entities are rarely taken into consideration. Burns states that in order for tourism to contribute to sustainable growth and wider societal development, the multiple sectors of the tourism industry and the various local industries should be involved together and cooperate in tourism planning. Similarly Müller (2011: 253) states that tourism has to be integrated into broader community development in order for it to be sustainable.

\section{Challenges of spatial concentration of tourism development}

Nelson and Winter (1982, as cited in Papatheodorou 2004: 222) have noted that typically tourist flows concentrate only in a small number of enterprises. This is because it is relatively easy to enter the tourism industry due to the low investment needs, but only a few businesses manage to achieve a reputation of expertise and a stable position in tourism markets. Strong tourism enterprises have a key role in triggering tourism development and starting to build up a destination (Pearce 1981: 16-19). As Papatheodorou (2004: 225-226) notes, market polarization is linked with the spatial polarization of tourism development due to the interdependence of economic and spatial dynamics. Nature-based tourism, in particular, is a strongly place-based branch of economy and, thus, tourism businesses are typically located around tourist pull factors and form business clusters (Huybers \& Bennett 2003: 572; Braun 2005: 5). That is, tourism and its impacts commonly spread unevenly in space (Williams \& Shaw 1998: 12; Hall \& Page 1999: 1). This can be considered challenging for the requirement of regional sustainability.

The spatial concentration of tourism development occurs at all spatial scales from local to global (Papatheodorou 2004: 225). Thus, core and periphery are relative concepts (Friedmann 1966). Britton's (1982) core-periphery model in tourism presents core-periphery relations on a global level. According to the model, tourist flows are orientated from the core, developed countries, to the peripheries, developing countries. Nevertheless, the power in tourism development remains in the core as the main tourism operators are located there. Tourist flows then concentrate in certain places in the peripheral areas in the destination countries which become enclave resorts. The outside areas cannot equally benefit from a resort's development. Gradually, these enclave resorts become core areas more prosperous in comparison with the surrounding periphery (Getz 1981; Weaver 1998; Walpole \& Goodwin 2000: 572; Kauppila 2011: 20, 22).

Such enclave tourist resort development is more extreme in the developing world. However, as Saarinen (2004: 171) notes, tourist resort development in the peripheries of the western countries clearly has similar challenges. Tourism-induced income and employment, public and private services and other facilities are often developing and maintained in tourism destinations, while surrounding spatial structures can decline socio-economically and politically. As a result, tourist resorts typically differentiate from their surrounding areas which then cannot equally benefit from the resorts' development. Although there are economic leakages outside tourist resorts (see Murphy 1985: 91), it is crucial to recognize the extent to which they fall on to the surrounding rural areas. Tourism operators in a resort can purchase products and services and hire employees from outside the region. According to Saarinen (2006: 49), in the current mode of development in Northern Finland, the links of tourism development to the local and 
regional traditional economies and production are not strong enough in regard to regional development.

As Kauppila (2004: 93) notes, in addition to economic impacts, innovativeness, the level of infrastructure and the possibilities for decision-making are typically greater at resorts. Caballos-Lascurain (1996: 13) has pointed out that enclave tourism development does not typically take into account the needs of the communities surrounding a resort. In the Whistler resort in Canada, a progrowth model of tourism development has led to the rise of no-growth interests among local residents. There has been a call for more affordable housing and schools, and a better consideration of environmental conditions affecting the residents' quality of life. Locals have wanted Whistler to be seen not only as a tourist resort but also as a community (Gill \& Williams 2011: 636, 638). Arell (2000: 125) has noted in the rural Scandinavian context that the spatial concentration of tourism development has had downsides to small-scale tourism enterprises located outside the resort. Also, in the Finnish Lapland, local villagers have experienced the resort-oriented tourism strategies as more beneficial to tourist resorts than to them (Hakkarainen \& Tuulentie 2008: 11).

In conclusion, tourism concentrates on certain areas because both natural characteristics of a region and its socioeconomic factors vary between different localities. As conceptualized by Brouder and Eriksson (2013: 378-379), regional socioeconomic structures offer distinct preconditions for a tourism sector to develop. The growth or the decline of the tourism industry in a certain region is affected by the economic development history of the region, i.e. previous events and choices made in the past. It is noteworthy, however, that in principle regional actors have the capability to alter the course of development, i.e. break the path dependence of development. Networking practices can be regarded as an example of such intentional actions.

\section{A call for network cooperation}

The wider regional economy could benefit from resort tourism development if tourism enterprises are capable of taking advantage of their close proximity and, at the same time, let positive income and employment impacts spread to surrounding areas (Agarwal 2012: 1473). In this process of tourism and community development, both tourism business networks (Novelli et al. 2006; Lagos \& Courtis 2008) and the connections of tourism businesses to other local livelihoods (Telfer \& Wall 2000; Saarinen 2006; Agarwal 2012; Graci 2013) have been considered vital. Network cooperation in tourism development can happen, for instance, in the process of marketing a tourism region. Typically, relatively small tourism enterprises can benefit from the economies of scale as they together create a critical mass of tourism enterprises and attractions which they then promote collectively to create a regional wellknown tourism brand (Meyer-Cech 2005: 146; Wang \& Fesenmaier 2007: 865).

The geographical proximity of firms in a business cluster has not been regarded as a sufficient condition to enhance knowledge transfer. Furthermore, cognitive, organizational, social, and institutional proximity impact how effortless interactive learning is (Boschma 2005: 71). Therefore, the joint actions of tourism actors, i.e. intentional cooperation, have a central role in fostering growth and competitiveness in rural tourism areas (Schmitz 1999: 468-469; Williams \& Copus 2005: $307,317)$. As Koster (2007) describes, "development of tourism at a regional level means the various communities, which comprise a region, will cooperate and integrate their collective attractions, capital, infrastructure, and natural and human resources in such a way to promote the region as a destination to potential tourists". Similarly Brouder and Eriksson (2013: 379-383) state that the economic success in rural communities is dependent on the capabilities of individuals and firms to exploit and recombine existing local human capital and create new knowledge. Intensified knowledge transfer is regarded to result in an increase in the adaptability of the enterprises, which then raises the innovativeness and competitiveness of a tourism region (Weidenfeld et al. 2010: 607, 617). Although the link between knowledge transfer and the growth in competitiveness has been difficult to prove empirically in the context of different fields of businesses and different spatial scales, the connection has been widely used as a theoretical starting point in network studies, also in tourism research (see Weidenfeld et al. 2010: 604).

Despite its importance, cooperation at a regional level has its challenges. As Carson et al. (2013: 13-14) note, tourism actors can have a low engagement to cooperate within an externally defined tourism region. This is due to the local culture of operating in isolation because of not know- 
ing the possible benefits of the cooperation activities, as well as to the reliance on public sector leadership. Tourism actors can have general lack of capacity to develop networking and cooperation practices, even locally. Weidenfeld et al. (2010: 617) have explained the lack of regional cooperation by tourism actors' unwillingness to learn from geographically proximate enterprises offering similar products due to their competitive relations. The distance, due to which competition grows too intense, is case-specific depending on, for example, tourist amounts. As Joshi et al. (2009: 241) note, a sense of solidarity would motivate entrepreneurs to cooperate.

Despite the challenges in cooperation at a regional level, even short-term and externally-managed cooperation networks aiming to increase tourism in rural areas can have significant longterm benefits for the community. Cooperation can increase tourism actors' knowledge on the benefits of sustainability for tourism and also for communal development. Moreover, they can give rise to the formation of new bottom up born cooperation in future (Conway \& Cawley 2012). As Brouder (2012) has pointed out, when tourism development is endogenous and local tourism networks exist, tourism can enhance geographically bounded social capital giving rise to further rural development.

\section{Case study area: Ruka resort in Kuusamo}

The case study area, the Kuusamo municipality of Finland, is a peripheral region at the national scale. It is sparsely populated and its natural environment is characterized by wilderness. Hence, tourism in Kuusamo is based on its pristine and topographically diverse natural environment. An important nature tourism attraction in the area is the PAN Park certified Oulanka National Park, with visitor numbers of 171,500 in 2011 (Metsähallitus 2012). Other pull factors are nature-based activities and accommodation, catering and transportation services (Kauppila 1997).

Clearly, however, the Ruka tourist resort (Fig. 2) still attracts most tourists travelling to Kuusamo. During the peak season, the resort can be considered a population center comparable to the municipality core when measured by the number of residents. A significant number of the tourism busi- nesses active in Kuusamo are located in Ruka. For instance, 23,000 out of the total 40,000 beds and 28 out of 64 restaurants are located in the resort (Ruka-Kuusamo Matkailuyhdistys 2013). This is partly explained by the strategic choices made in tourism planning: since the 1970s, substantial public investments have been aimed at developing tourism in Ruka. From the 1980s onwards, tourism in Ruka was institutionalized, and it attracted especially mass tourism. After the economic depression of the 1990s, a new phase of development started. The city of Kuusamo took part in the planning and a new tourism strategy was created (Kauppila 2009: 227-229). In 2000, the number of tourism overnight stays in Kuusamo was 260,000, and by the year 2010, the number had increased to 430,000 (Kauppila 2012: 28). Measured by growth in visitor numbers, tourism development has been successful during this period.

The aim of the Ruka tourism strategy created by the town of Kuusamo in 2000 was to develop Ruka into an international, year-round, diverse tourist resort that is connected with the wider tourism region (Kuusamon kaupunki 2000: 5-6). In the vision for Ruka, the following was outlined:

". - - . Businesses and societies will cooperate in producing leisure activities and services for business travel. In all practices, the principles of sustainable development will be followed and environmental values will be taken into account. Local cultural history and diversity and pristine wilderness and fell environments and waterways will be the pull factors of tourism products. - - -"

As one part of the strategy, the town hired Ecosign Mountain Resort Planners Ltd. to make a tourist resort plan for Ruka between 2001-2003. The plan was to contribute to the strategic aims set (Kuusamon kaupunki 2000: 5). The starting point for the planning work was the idea of a tourist resort as a compact, "humanly pleasing" pedestrian village. Accommodation facilities were to be situated within a walking distance of the services. Compact planning was said to contribute to sustainable development, which in this case referred to its ecological aspects. Another principle goal of the planning was fostering regional cooperation, which meant marketing, trail maintenance, and other development work was to be done by a collective organization to which membership was to be compulsory (Leikoski 2005: 116-117). Today, the Ruka pedestrian village (see Fig. 2) hosts over 1000 beds, 15 restaurants, ten shops, and an un- 


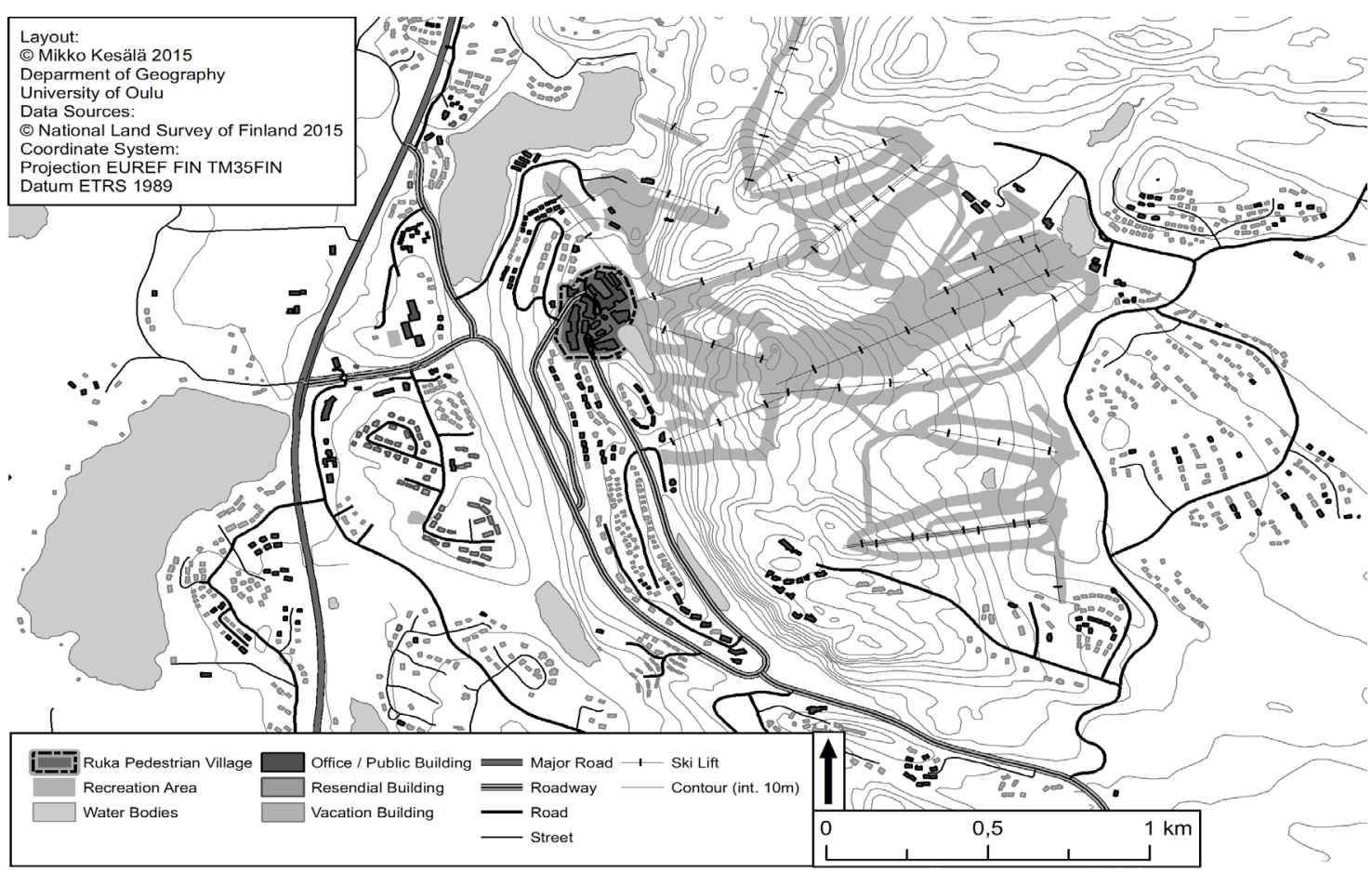

Fig. 2. Map of the Ruka resort and the Ruka pedestrian village.

derground parking hall right next to the slopes (Ruka-Kuusamo Matkailuyhdistys 2014a). In addition, there are tourism businesses located outside the village.

Tourism development has evidently created income and employment in Kuusamo. Compared with other local industries, tourism offers the most employment opportunities. The direct employment impact of tourism industry was 674 full-time equivalent jobs in $2010,7.9 \%$ of which fell to non-local seasonal workers (Kauppila 2012: 22, 32). However, as Kauppila (2004, 2011: 25-26, 28 ) has noted, the socio-economic benefits are unevenly distributed spatially within the region. According to him, the number and structure of the enterprises, jobs and permanent population have increased in the resort as the surrounding areas in the municipality have declined. For instance, the permanent population of Ruka has increased from 175 to 347 during 1970-2007. If seasonal residents (workers, telecommuters and second home owners) were included in the numbers, the growth would be even higher. Kuusamo, as a whole, still faces the common challenges of the so-called less favored areas: the population of 16,000 residents decreases and the unemployment rate of $14.7 \%$ (2013) is higher than the national average (Kuusamon kaupunki 2011; Pohjois-Pohjanmaan ELY-keskus 2013). According to Kauppila (2011: 27-28), due to this polarization process, Ruka has become a core located in a periphery in a northern periphery. There seems to be a need to reassess the extent to which tourism development in its current mode is capable of fostering the socio-economic well-being of local communities in Kuusamo.

\section{Research method}

In this preliminary study, the research data consists of semi-structured interviews conducted by the author with ten tourism actors in Ruka in November 2012. Interviews were chosen as the data collection method since the interest was to look at not only the spatial form of local tourism networks but also to see how the actual networking practices 
are interconnected to the interviewees' conceptions on tourism business networking and the destination. Lynch et al. (2000) state that by studying human behavior it is possible to map the structure of networks and, at the same time, gain more indepth knowledge about the attitudes and values that impact behavior. It is possible to picture the networks both from the actors' perspective and from 'above' (Tinsley \& Lynch 2001: 370). The chosen research method connects with the theory of structuration by Giddens (1979: 69) which sees structure and agency in a dialectical relationship. That is, structures impact the behavior of actors but, at the same time, their action (re)produces these structures. For instance, a business environment can affect how tourism actors view the importance of networking and are then willing to cooperate. Then, their actions impact the kind of cooperation environment that is built.

The interviewees were selected based on purposeful sampling from the contacts obtained in a previously conducted research in the area. Nine of the interviewees are either management-level employees or entrepreneurs in local tourism businesses and one was the executive manager of the Ruka-Kuusamo Tourism Organization at the time. Measured by the employment capacity, six of the enterprises are small (1-10 full-time equivalent jobs) and three are large (21 or more full-time equivalent jobs) in the Kuusamo context. The interviewed actors represent the fields of businesses in tourism which get direct tourism income and which are expected to cooperate on tourism service production. These include three program providers, two accommodation agencies, one accommodation and catering service, one ski lift company, one maintenance company, one taxi company, and one regional tourism organization. Almost all the enterprises produce services in other fields of businesses as well. For instance, five enterprises provide accommodation and catering services. Due to the geographical focus of the current preliminary study, all the enterprises are located in the Ruka resort.

The interviewees were asked about their thoughts on networking: the current state of cooperation, its importance and benefits, challenges and hoped-for future prospects. By including the spatial dimension in the conversation, it was possible not only to illustrate the spatial construction of the networks but also to understand the social factors that impact the networking. In the interviews, most informants candidly related about their views on the sensitive topic by telling about their experiences and expressing their personal opinions. However, a clear minority did not readily discuss the negative experiences of cooperation, especially if those were connected to a specific enterprise. Also, whether the interviewees expressed their personal opinions or those that fit the official stance of the company varied between, but also within, the interviews.

On the whole, however, results do not represent the 'airbrushed' state of networking but include the sensitive issues impacting the spatial construction of the cooperative networks. That was the main goal in using interviews as the data collection method. The collected data was analyzed by qualitative content analysis. The aim was to discover how the conceptions of networking differed according to the company's location within the resort. Attention was also given to the ways how the interviewees perceive their enterprises' spatial sphere of operations, as well as to Ruka and Kuusamo as spatial entities. Although the current interview data is not representative enough for a detailed quantitative analysis on the spatiality of tourism business cooperative relations, the collected data proved to be sufficient for answering the research question: "How are the local tourism business cooperative networks of the Ruka tourist resort spatially constructed within the RukaKuusamo tourism destination?"

\section{Types and scales of cooperation}

The tourism actors in Ruka acknowledge that their enterprises can benefit from tourism business cooperation. Most often improving the enterprise's reputation - usually the international reputation was seen as the main benefit. In addition, the possibility of using the services and resources of other enterprises to complement one's own products and services was considered important. Although the interviewees noted that they do not always have enough resources to cooperate, they underlined the significance of the cooperation practices in Ruka-Kuusamo. Cooperation was described as "the only way to success", "the lifeline of everything" and "the cornerstone of operations". However, the tourism actors had diverging opinions about which kinds of cooperation were the best for achieving the desired benefits as well as within which areas to cooperate. These issues will be considered next. 


\section{Joint marketing at the regional scale}

When asking the interviewees about whether the enterprises in Ruka cooperate with businesses located outside the resort, i.e. elsewhere in Kuusamo, the interviewees answered in the affirmative. Evidently, however, tourism businesses cooperate at a regional scale mainly in joint marketing. They agree on its importance in regard to tourism destination competitiveness. Increasing the prominence of the tourist destination was hoped to result in increased numbers of tourists in the region, which was regarded as a benefit by both small and large businesses. It seems that even the largest companies do not have enough resources to gain an international reputation on their own.

In Kuusamo, destination-scale joint marketing is coordinated by the Ruka-Kuusamo Tourism Organization, which was founded in 2002 by the largest tourism businesses in the region and by the town of Kuusamo (Ruka-Kuusamo Matkailuyhdistys 2014b). Today, the organization is comprised of 160 member companies (Rytkönen 2012) who represent $90 \%$ of all the tourism revenue received by the tourism enterprises in the municipality. The organization is responsible for marketing the tourism region both in Finland and internationally (Ruka-Kuusamo Matkailuyhdistys ry 2014c).

However, in some enterprises, joint marketing at the municipality scale may not be considered a priority in their marketing cooperation practices. One of the interviewed entrepreneurs (from a large company operating in the Ruka pedestrian village) noted that in order to achieve an international reputation, joint marketing should be done in a larger area than just the municipality. He described this as follows:

\footnotetext{
"Of course we try to push the regional cooperation forward all the time, to expand it. And I see that in international tourism the whole Northern Finland is this area. When the aim is to go to the international markets, there Kuusamo is such a small region that its money is definitely not enough to make itself visible. If the whole Northern Finland is there, its money is in a league of its own. Then it is possible to even achieve something visible."
}

According to the interviewee, the more businesses participating in marketing cooperation, the better. However, he did not believe that it was essential to have the small enterprises located outside the resort involved in the joint marketing. From the perspective of the interviewed small enterprises, this issue was somewhat different. They want to be involved in joint marketing. Furthermore, they wish to ensure that all cooperating enterprises get their share of the tourist flows and income. There is a call for joint sales in which the practice of allocating the income is agreed upon in advance. In this way, enterprises would cooperate not only in attracting customers to the region but also in sharing the "business pie" created (cf. Brandenburger \& Nalebuff 1998: 14).

As the results show, it is mainly marketing cooperation that happens at a regional scale. It is worth noting that although the member companies cooperate on marketing activities, this does not necessarily mean that they cooperate in practice or are in contact with each other. Formal joint marketing relations, at their narrowest, can be based solely on belonging to the same organization, i.e. paying the membership fee.

\section{Spatial concentration of cooperative production networks}

Unlike in joint marketing, production cooperation requires of an enterprise at least some knowledge of other businesses and their services, actual contact with them, or joint actions. In this paper, the concept "production cooperation" refers to those activities that enterprises do together in order to produce tourism services (e.g. accommodation, programs, catering) for their customers. This occurs, for instance, when an enterprise buys products or services from another company. If a cooperating partner operates as a subcontractor, the product is offered to the customers under the name of the main supplier. Alternatively, businesses can work as more equal partners, in which case products may also be developed in cooperation. Production cooperation can be planned, for example, in the long-term joint production of program providers, or it can happen on an ad hoc basis, as in event production.

The need to cooperate in service production emerges because businesses tend to specialize only in some tourism services, and few enterprises are capable of offering all the services customers need during their stay. Production cooperation can occur between the fields of tourism business (e.g. accommodation service buying program services), within a field of business (e.g. larger program providers buying services from smaller enterprises such as reindeer or husky farms or fishing program providers) or even between businesses offering similar 
products (e.g. when a program provider hires extra staff or equipment from a similar business).

In the Ruka resort, enterprises cooperate in producing tourism services, and businesses have lasting and well-functioning cooperation partnerships. Nevertheless, it is noteworthy that cooperative production networks appear to concentrate geographically. The majority of cooperative networks are clustered in the Ruka pedestrian village which is the very core area of the Ruka resort, although, some businesses utilize services outside the pedestrian village as well as outside the resort. That is, the area of most cooperation in production is yet smaller than the resort and seems to exclude the enterprises located outside the very core.

According to the interviewees operating in the pedestrian village, cooperation functions well there. Enterprises located in the village have cooperated for years, and interviewees claimed that there was a good spirit among the oldest companies. The interviewed tourism actors distinguish the pedestrian village, built at the foot of the front slopes, from the other parts of the resort. The tourism actors in the village, as well as those operating outside of it, refer to the very core area as "the Ruka village", "the upper village" or "the center of Ruka". The village borders namely refer to the pedestrian village, which the interviewees described as being situated "high up" and "on top". For instance, the upper village is clearly marked as separate from the business area located away from the slopes further downhill, which is referred to as 'down' in comparison to the pedestrian village.

The main body organizing the business cooperation in the village is the Ruka Pedestrian Village Organization (hereafter RPVO). Its aim is to put the village on the map, improve its attractiveness, increase customer numbers, and make the operational preconditions better for the tourism actors in the village (Rukan kävelykyläyhdistys ry 2014). In principle, businesses located outside the village are also allowed to join the association. However, one interviewee mentioned:

"Joining the association actually gets an enterprise nowhere as such if it is located further away. In the constitution of the organization it is outlined that the actions are tethered to the upper village here. The aim of all the association's operations is to increase the revenue of the member companies. If an event is organized, it is organized here; we never go down there, close to the grocery store, to do it. Then it does not really benefit them [the companies located outside the pedestrian village] at all."
The member businesses of the RPVO are mainly located in the pedestrian village, which the interviewees considered understandable. The interviewee justified the sphere of the organization's actions by the constitution of the village that he presented as neutral, as if defined by an outsider. Thus, the interviews show that tourism actors in the pedestrian village perceive the operational environment of their businesses as being concentrated in the pedestrian village. The interviewed entrepreneurs located in the pedestrian village see the benefits of production cooperation to be best achieved by cooperating at the village scale. This was evident in the comments of one interviewee:

"Absolutely, it is important that the tourism entrepreneurs cooperate in Ruka. Otherwise we would not have founded this kind of Ruka Pedestrian Village Organization in the area. Around 90 percent of all the businesses in the village are now members. The only way to succeed is to cooperate."

From the perspective of the interviewed businesses located outside the pedestrian village elsewhere in Ruka, the current scale of production cooperation perceived differently. Many of the interviewed actors see the business connections with the Ruka pedestrian village as beneficial, and hence, consider it problematic that the cooperative production networks of the village are mainly concentrated in that area. An entrepreneur from outside the village illustrated his experience of COoperation with the village as follows:

"They are so big and strong companies and they cooperate with each other. It is very difficult to get in. I have tried it, with very bad results, though. With such results that I will not go there again."

One possible way to enter the village cooperative networks was said to be to open a new office for one's enterprise in the village. However, the high rents were considered as hindering small businesses from operating at the very core of Ruka. Another possibility of gaining access was to cooperate with an enterprise that is located elsewhere in Kuusamo but also has an office in the pedestrian village.

Consequently, the pedestrian village was found to be a space where it is hard for tourism actors located outside to go and do business. Furthermore, the interviewees indicated that the use of public spaces is governed rather by the businesses in the village than the town of Kuusamo, which owns the land. For instance, some of the business actors operating outside the very core felt that they 
are not allowed to bring promotional material to the pedestrian village. It seems that to the tourism actors located outside the village, the area is seen as more of a private than a public space.

Based on the study results, the tourism enterprises in Ruka are interested in cooperating with such tourism areas that have better visibility and attract more tourists than their own. Commonly, the enterprises located outside the pedestrian village hope to cooperate with the village, whereas the businesses at the very core wish to get connections to the higher regional level. At the same time, the aim of the businesses to keep their customers within the range of their company in order to get as large a share as possible of tourists' spending seems to reduce the willingness to cooperate. To the businesses in the pedestrian village, cooperation in production with the enterprises outside the core does not always seem essential since they are able to capitalize on the natural environment of the surrounding areas without cooperation, for instance, by having their own accommodation and safaris in the surrounding areas. Furthermore, as most tourist flows concentrate in the core area of the resort, there does not seem to be a strong need for production cooperation with the surrounding areas.

\section{Discussion and conclusions}

This paper has given an account of the local-scale tourism networking in the rural areas of resort-oriented tourism development. As the study results have demonstrated, resort-oriented tourism development seems to make cooperative networks similarly resort-centered. The businesses located in the Ruka resort cooperate at the Ruka-Kuusamo destination scale mainly in marketing while their partners in production cooperation are located mostly within the resort. The cooperative production networks, the ones that require actual contact and joint actions with other businesses, concentrate particularly in the very core area of the resort. This contributes mainly to the development of the core areas alone and hinders the surrounding rural areas from benefitting from the positive impacts of tourism development, since it is production cooperation that could channel tourism income spatially. Currently, production cooperation is likely to be insufficient distributing the benefits of tourism development in the way whereby the Finnish tourism strategies intend them to do. In regard to strengthen the sustainable regional development impacts of tourism, cooperation in marketing should not be regarded as a sufficient way to cooperate.

This paper has demonstrated that, for smaller enterprises outside the core, it can be difficult to benefit from the growth of the resort's core and its tourist flows through network relations. This is because the role of the businesses located outside the resort may be regarded as inconsequential by some tourism actors. The experiences of small enterprises indicate their lack of power in networks. This is due to the fact that production cooperation with the surrounding areas is not essential to the large enterprises in the very core. Therefore, they are able to exclude the smaller enterprises located outside the core from the cooperative production networks. For the businesses in the Ruka pedestrian village, resort-centered cooperation in tourism production seems justified in terms of tourism growth. As noted by Koster (2007: 140), a shortsighted interest in developing an individual community only creates resistance to cooperate within the scope of the wider tourism region.

Spatial concentration of the cooperative networks can have, in the long run, negative effects also on the growth and development of the businesses in the core. In a case where local SMEs in the surrounding areas are left out of the networks, it is axiomatic that their knowledge of and connections to the local community and natural environment are also excluded from tourism services. As Arell (2000: 131) has pointed out, when enterprises network effectively within a large area and utilize the local traditions and know-how of older generations for the tourism development of today, the tourism region can become creative and successful. Similarly Brouder and Eriksson (2013: 138) note that the access to and the invocation of local knowledge contributes to the survival of new micro-firms in the rural tourism industry. In terms of tourism supply, by way of core-periphery cooperation, it would be possible to diversify the supply of services of the destination and attract a wider range of market segments (Viken \& Aarsaether 2013: 38). In the case of the Finnish Lapland, the local characteristics could be utilized for profiling the relatively similar tourist resorts (Lapin liitto 2007: 31). Based on the aforementioned notions of long-term business success and sustainable regional development, a move towards a destination region-based tourism should be made. Then, tourism development would better contribute to socioeconomic development and well-being in local communities. 


\section{Spatial identification and destination development}

Based on the results of the current study, there is a social division and lack of networking between the core and the surrounding areas in Kuusamo. The tourism actors in the Ruka resort typically associate themselves primarily with the closest sphere of operations. For actors who are located in the very core of the resort, this area can be very small, the Ruka pedestrian village. The pedestrian village located 'up' appears to be higher not only in altitude but also in the tourism actors' perceptions of value. That is, resort-oriented tourism development has created a space in a resort weakly connected to the local small-scale tourism development outside the core via networking relations. Thus, the core is a differentiated area not only measured by its economic and demographic characteristics but also in a sociocultural sense. This attests to the enclave nature of resort-oriented tourism development also in the Scandinavian context.

The tourist resort appears to function as a basis for spatial identification for tourism actors. However, there is not necessarily one clear or a collectively shared identity. The tourism actors within the resort are not an internally homogeneous group. The heterogeneity of the local actors creates challenges for the destination development. The spatial scale of identification seems to be significant in determining which area is conceived as the area for tourism growth and development. When entrepreneurs perceive the resort as the principal area of their operations, they do not particularly engage with the surrounding rural areas and businesses or with other actors located there. Then, this affects how entrepreneurs are motivated to cooperate at the local and regional scale. The current study has demonstrated how the spatial identification of local tourism actors is linked to the spatial construction of local and regional tourism networks.

From another perspective, networking practices have a role in (re)producing tourism destinations as social and functional spatial entities. This is because, as with any region, also tourism destinations are constructs that are continuously built and re-built in socio-spatial practices at different spatial scales. Regional structures affect the way local actors identify with the region and, in turn, produce it in their daily (net)working practices. In other words, the becoming of a tourism destination is affected simultaneously by territorial and relational processes. While these processes oper- ate in the global-local nexus, they are also locallybased and historically contingent (see Paasi 1991, 2009, 2011). As the current study has indicated, the spatial identification of tourism actors is connected to the construction of local tourism networks. In tourism research, attention should be paid to this co-constitution of territorial structures and relational agency in tourism destination transformation, as Saarinen (2014: 51) has argued. Thus, it will be central to study local tourism stakeholder's views and agency related to tourism networking and destination change. Pro-sustainable tourism research and policies should recognize and encourage local tourism actors' possibilities to take part in local tourism networks, reproduce them, and, in this way, affect the course of destination's future development.

\section{ACKNOWLEDGEMENTS}

I highly appreciate the anonymous Reviewers for their comments that improved the manuscript. I am also grateful to the colleagues at the department of geography for their advice, especially to Mikko Kesälä for making the maps. I would like to acknowledge the Academy of Finland for research funding (RELATE CoE, 272168).

\section{REFERENCES}

Agarwal S 2012. Resort economy and direct economic linkages. Annals of Tourism Research 39: 3, 1470-1494. http://dx.doi.org/10.1016/j.annals.2012.04.001.

Arell N 2000. The evolution of tourism in the Tärna Mountains. In Brown F \& Hall D (eds). Tourism in peripheral areas: case studies, 91-100. Channel View Publications, Clevedon, UK.

Boschma RA 2005. Proximity and innovation: a critical assessment. Regional Studies 39: 1, 61-74. http://dx.doi.org/10.1080/0034340052000320887.

Brandenburger AM \& Nalebuff BJ 1998. Co-opetition. Doubleday, New York.

Braun P 2005. Creating value to tourism products through tourism networks and clusters: uncovering destination value chains. In Proceedings of the OECD-Korea international tourism conference "Global tourism growth: a challenge for SMEs". Gwangju, Korea, September 6-7, 2005.

Britton SG 1982. The political economy of tourism in the Third World. Annals of Tourism Research 9: 3 , 331-358.

http://dx.doi.org/10.1016/0160-7383(82)90018-4.

Brouder P 2012. Creative outposts: tourism's place in rural innovation. Tourism Planning \& Development 9: 4, 383-396.

http://dx.doi.org/10.1080/21568316.2012.726254. 
Brouder P \& Eriksson RH 2013. Staying power: what influences micro-firm survival in tourism? Tourism Geographies: An International Journal of Tourism Space, Place and Environment 15: 1, 125-144. http://dx.doi.org/10.1080/14616688.2011.647326.

Burns PM 1999. Paradoxes in planning. Tourism elitism or brutalism? Annals of Tourism Research 26: 2, 329-348. http://dx.doi.org/10.1016/S0160-7383(98)00099-1.

Burns PM 2004. Tourism planning: a third way? Annals of Tourism Research 31: 1, 24-43. http://dx.doi.org/10.1016/j.annals.2003.08.001.

Caballos-Lascurain H 1996. Tourism, ecotourism and protected areas. IUCN, Gland, Switzerland.

Carson DA, Carson DB \& Hodge H 2013. Understanding local innovation systems in peripheral tourism destinations. Tourism Geographies: An International Journal of Tourism Space, Place and Environment 16: 3, 457-473. http://dx.doi.org/10.1080/14616688.2013.868030.

Conway T \& Cawley M 2012. Organizational networking in an emerging ecotourism destination. Tourism Planning \& Development 9: 4, 397-409. http://dx.doi.org/10.1080/21568316.2012.726256.

Friedmann J 1966. Regional development policy: a case study of Venezuela. The M.I.T. Press, Massachusetts.

Getz D 1981. Tourism and rural settlement policy. Scottish Geographical Magazine 97: 3, 158-168. http://dx.doi.org/10.1080/00369228108736501.

Giddens A 1979. Central problems in social theory. Action, structure and contradictions in social analysis. Macmillan, London.

Gill AM \& Williams PW 2011. Rethinking resort growth: understanding evolving governance strategies in Whistler, British Columbia. Journal of Sustainable Tourism 19, 4-5: 629-648. http://dx.doi.org/10.1080/09669582.2011.558626.

Graci S 2013. Collaboration and partnership development for sustainable tourism. Tourism Geographies: An International Journal of Tourism Space, Place and Environment 15: 1, 25-42.

http://dx.doi.org/10.1080/14616688.2012.675513.

Hakkarainen M \& Tuulentie S 2008. Tourism's role in rural development of Finnish Lapland: interpreting national and regional strategy documents. Fennia 186: 1, 3-13.

Hall CM \& Page SJ 1999. The geography of tourism and recreation: environment, place and space. Routledge, London.

Huybers T \& Bennett J 2003. Inter-firm cooperation at nature-based tourism destinations. Journal of Socio-Economics 32, 571-587. http://dx.doi.org/10.1016/j.socec.2003.08.011.

Joshi A, Lazarova M \& Liao H 2009. Getting everyone on board: the role of inspirational leadership in geographically dispersed teams. Organization Science 20: 1, 240-252. http://dx.doi.org/10.1287/orsc.1080.0383.

Kauppila P 1997. Miksi Kuusamoon? Tutkimus Kuusamon kesävetovoimatekijöistä. Nordia Tiedonantoja 3. Pohjois-Suomen maantieteellinen seura ja Oulun yliopiston maantieteen laitos, Oulu.

Kauppila P 2004. Matkailukeskusten kehitysprosessi ja rooli aluekehityksessä paikallistasolla: esimerkkeinä Levi, Ruka, Saariselkä ja Ylläs. Nordia Geographical Publications 33: 1. The Geographical Society of Northern Finland and the Department of Geography, University of Oulu, Oulu.

Kauppila P 2009. The development process of Ruka tourist resort. In Hall M, Müller DK \& Saarinen J (eds). Nordic tourism. Issues and cases, 226-229. Channel View Publications, Bristol.

Kauppila P 2011. Cores and peripheries in a northern periphery: a case study in Finland. Fennia 189: 1, 20-31.

Kauppila P 2012. Matkailu, kaivostoiminta ja aluekehitys: esimerkkeinä Kuusamo, Kittilä ja Sotkamo. In Kauppila P \& Kuosku K (eds). Kuusamon aluetalousraportti. Tutkimuksia 1/2012, 44-168. Koillis-Suomen Naturpolis kehittämisyhtiö Oy, Kuusamo.

Koster R 2007. A regional approach to rural tourism development: towards a conceptual framework for communities in transition. Loisir et Société / Society and Leisure 30: 1, 133-156. http://dx.doi.org/10.1080/07053436.2007.10707743.

Kuusamon kaupunki 2000. Ruka 2005. Unpublished report. Kuusamon kaupunki, Kuusamo.

Kuusamon kaupunki 2011. Talousarvio 2012. Taloussuunnitelma 2013-2014. Kuusamon kaupunki.

Lagos D \& Courtis PG 2008. Business clusters formation as a means of improving competitiveness in the tourism sector. European Research Studies XI, 1-2.

Lapin liitto 2007. Lapin matkailustrategia 2007-2010. Julkaisu A22/2008. Lapin liitto, Rovaniemi.

Lapin liitto 2011. Lappi - elämänvoimaa. Matkailustrategia 2011-2014. Lapin liitto, Rovaniemi.

Leikoski E (ed) 2005. Ruka. Ensimmäiset 50 vuotta. Rukakeskus Oy, Helsinki.

Lynch P, Halcro K, Johns N, Buick I \& Gillham M 2000. Networks and networking: a strategic tool for small hotel survival and success? In Williams A (ed). Proceedings of the 9th Annual CHME hospitality research conference, 114-124. Huddersfield, April 26-27, 2000.

Metsähallitus (2012). Kansallispuistojen, valtion retkeilyalueiden ja eräiden muiden suojelu- ja virkistysalueiden kävijöiden rahankäytön paikallistaloudelliset vaikutukset vuonna 2011. <http://www.metsa.fi/sivustot/metsa/fi/Eraasiatjaretkeily/Virkistyskaytonsuunnittelu/suojelualueidenmerkityspaikallistaloudelle/Sivut/Kansallispuistoihinsijoitetutrahatpalautuvatmonikertaisina. asp $x>21.02 .2014$.

Meyer-Cech K 2005. Regional cooperation in rural theme trails. In Hall D, Kirkpatrick I \& Mitchell M (eds). Rural tourism and sustainable business, 137-148. Channel View Publications, Clevedon, UK.

Montanari A \& Williams AM 1995. Introduction: tourism and economic restructuring in Europe. In 
Montanari A \& Williams AM (eds). European tourism, 1-15. John Wiley \& Sons, Chichester.

Murphy P 1985. Tourism: a community approach. Methuen, London.

Müller DK 2011. Conclusion: Polar tourism for regional development? In Grenier AA \& Müller DK (eds). Polar tourism: a tool for regional development, 251-255. Presses de I'Université du Québec, Québec.

Müller DK \& Brouder P 2014. Dynamic development or destined to decline? The case of Arctic tourism businesses and local labour markets in Jokkmokk, Sweden. In Viken A \& Granås B (eds). Tourism destination development: turns and tactics. Ashgate, Farnham.

Nelson R \& Winter S 1982. An evolutionary theory of economic change. Harvard University Press, Cambridge.

Novelli M, Schmitz B \& Spencer T 2006. Networks, clusters and innovation in tourism: a UK experience. Tourism Management 27: 6, 1141-1152. http://dx.doi.org/10.1016/j.tourman.2005.11.011.

Oppermann M 1996. Rural tourism in southern Germany. Annals of Tourism Research 23: 1, 86-102. http://dx.doi.org/10.1016/0160-7383(95)00021-6.

Paasi A 1991. Deconstructing regions: notes on the scales of spatial life. Environment and Planning $A$ 23: 2, 239-256.

http://dx.doi.org/10.1068/a230239.

Paasi A 2009. Regional geography I. In Kitchin R \& Thrift N (eds). International encyclopedia of human geography, 214-277. Elsevier, Amsterdam.

Paasi A 2011. The region, identity, and power. Procedia Social and Behavioral Sciences 14, 9-16. http://dx.doi.org/10.1016/j.sbspro.2011.03.011.

Papatheodorou A 2004. Exploring the evolution of tourism resorts. Annals of Tourism Research 31: 1, 219-237.

http://dx.doi.org/10.1016/j.annals.2003.10.004.

Pearce DG 1981. Topics in applied geography. Tourist development. Longman, London.

Pohjois-Pohjanmaan ELY-keskus 2013. Työllisyyskatsaus 06/2013. <http://www.ely-keskus.fi/documents/10191/235106/Tyollisyyskatsaus_kesakuu_2013.pdf/effbbcc6-4349-4221-9ae0d8d9418c9234> 19.08.2014.

Pohjois-Pohjanmaan liitto 2011. Pohjois-Pohjanmaan matkailustrategia 2015. Pohjois-Pohjanmaan liitto, Oulu.

Ribeiro M \& Marques C 2002. Rural tourism and the development of less favoured areas. International Journal of Tourism Research 4, 211-220. http://dx.doi.org/10.1002/jtr.377.

Ruka-Kuusamo Matkailuyhdistys ry 2013. Rukan ja Kuusamon matkailun faktoja. <http://www.ruka. fi / talvi/etusivu/? file = content_ exec\&id=140\&submenu=174>10.10.2013.

Ruka-Kuusamo Matkailuyhdistys ry 2014a. Rukan ja Kuusamon matkailun faktoja. <http://www.ruka. fi / talvi/etusivu/? fil e = content_ exec\&id=140\&submenu=174> 27.02.2014.
Ruka-Kuusamo Matkailuyhdistys ry 2014b. Ruka-Kuusamo matkailuyhdistys ry. <http://www.ruka.fi/talvi/ yritykset/?file=target_exec\&id=886> 24.02.2014.

Ruka-Kuusamo Matkailuyhdistys ry 2014c. RukaKuusamo Matkailuyhdistys. <http://www.rukax. fi/web/guest/yhdistys > 24.02.2014.

Rukan kävelykyläyhdistys ry 2014. Rukan kävelykyläyhdistys ry. <http://www.rukankavelykylayhdistys.fi/index.asp $>21.03 .2014$.

Rytkönen T 2012. Executive manager of Ruka-Kuusamo Tourism Organization. Interview conducted in Ruka, 16.10.2012.

Saarinen J 2004. 'Destinations in change'. The transformation process of tourist destinations. Tourist Studies 4: 2, 161-179. http://dx.doi.org/10.1177/1468797604054381.

Saarinen J 2006. Tourism in peripheries: the role of tourism in regional development in Northern Finland. In Müller D \& Jansson B (eds). Tourism in peripheries: perspectives from the Far North and South, 41-52. CABI Publishing, Wallingford.

Saarinen J 2008. Contradictions of rural tourism initiatives in rural development contexts: Finnish rural tourism strategy case study. Current Issues in Tourism 10: 1, 96-105. http://dx.doi.org/10.2167/cit287.0.

Saarinen J 2014. Critical sustainability: setting the limits to growth and responsibility in tourism. Sustainability $6,1-17$. http://dx.doi.org/10.3390/su6010001.

Schmitz H 1999. Collective efficiency and increasing returns. Cambridge Journal of Economics 23, 465-483. http://dx.doi.org/10.1093/cje/23.4.465.

Telfer DJ \& Wall G 2000. Strengthening backward economic linkages: local food purchasing by three Indonesian hotels. Tourism Geographies: An International Journal of Tourism Space, Place and Environment 2: 4, 421-447. http://dx.doi.org/10.1080/146166800750035521.

Tinsley R \& Lynch P 2001. Small tourism business networks and destination development. Hospitality Management 20: 4, 367-378. http://dx.doi.org/10.1016/S0278-4319(01)00024-X.

Työ- ja elinkeinoministeriö 2010. Suomen matkailustrategia 2020. Työ- ja elinkeinoministeriö, Helsinki.

Viken A \& Aarsaether N 2013. Transforming an iconic attraction into a diversified destination: the case of North Cape tourism. Scandinavian Journal of Hospitality and Tourism 13: 1, 38-54.

http://dx.doi.org/10.1080/15022250.2013.771994.

Walpole MJ \& Goodwin HJ 2000. Local economic impacts of dragon tourism in Indonesia. Annals of Tourism Research 27: 3, 559-576. http://dx.doi.org/10.1016/S0160-7383(99)00088-2.

Wang Y \& DR Fesenmaier 2007. Collaborative destination marketing: a case study of Elkhart county, Indiana. Tourism Management 28, 863-875. http://dx.doi.org/10.1016/j.tourman.2006.02.007.

Weaver DB 1998. Peripheries of the periphery: tourism in Tobago and Barbuda. Annals of Tourism Research 25: 2, 292-313. 
http://dx.doi.org/10.1016/S0160-7383(97)00094-7.

Weidenfeld A, Williams AM \& Butler RW 2010.

Knowledge transfer and innovation among attractions. Annals of Tourism Research 37: 3, 604-626. http://dx.doi.org/10.1016/j.annals.2009.12.001.

Williams F \& Copus A 2005. Business development, rural tourism, and the implications of milieu. In
Hall D, Kirkpatrick I \& Mitchell M (eds). Rural Tourism and Sustainable Business, 305-322. Channel View Publications, Clevedon, UK.

Williams AM \& Shaw G 1998. Tourism \& economic development. European experiences. John Wiley \& Sons, Chichester. 